2015, volume 4, issue 2

Peršić M., Bakija K., \& Vlašić D. (2015). Framework for improving quality and comparability of non-financial reporting system. Copernican Journal of Finance \& Accounting, 4(2), 109-127. http://dx.doi.org/10.12775/CJFA.2015.019

\author{
Milena Peršıć \\ University of Rijeka, Faculty of Tourism and Hospitality Management, \\ Accounting Department \\ KATARINA BAKIJA** \\ DOBA, Faculty of Applied Business and Social Studies \\ Dubravka Vlašıć ${ }^{* * *}$ \\ University of Rijeka, Faculty of Tourism and Hospitality Management, \\ Accounting Department

\section{FRAMEWORK FOR IMPROVING QUALITY AND COMPARABILITY OF NON-FINANCIAL REPORTING SYSTEM}

Keywords: Non-financial information, CSR, Directive 2014/95/EU, Strategic accounting, Sustainability reporting.

J E L Classification: M4, Q56.

Abstract: This research was aimed at evaluating the methodological framework to be applied in strategic as well as in responsibility accounting, as a prerequisite for ensu-

Date of submission: June 5, 2015; date of acceptance: October 27, 2015.

* Contact information: milena.persic@fthm.hr, University of Rijeka, Faculty of Tourism and Hospitality Management, Accounting Department, Opatija, Croatia, phone: +38551290689 .

** Contact information: kbakija@net.hr, DOBA, Faculty of Applied Business and Social Studies, Maribor, Slovenia, phone: +385992110386.

${ }^{* * *}$ Contact information: Dubravka.vlasic@fthm.hr, University of Rijeka, Faculty of Tourism and Hospitality Management, Accounting Department, Opatija, Croatia, phone: +38551290881. 
ring the relevant information, necessary for preparing and evaluating sustainable development strategies, using Directive 2014/95/EU framework. In order to assess the current situation in the Republic of Croatia, a survey on the sample of 64 big Croatian companies in different industries in the year 2013 was conducted. The sample of selected companies was chosen on the basis of membership in the Croatian Business Council for Sustainable Development (HR BCSD) and of the companies that follow the principles of sustainable development in their business and declare themselves as environmentally and socially responsible. Research results will be confirmed through comparison with previous findings conducted in the year 2007, but also compared with the relevant information collected from 71 companies of eight EU countries. The goal is to assess whether the achieved level of strategic and sustainable accounting tools in the Croatian companies are sufficient to provide relevant information for non-financial reporting for external and internal users in the process of long and short term decision making. Recognized gaps will be the starting points for defining the opportunities and areas in the process of harmonization between internal and external sustainability reporting system. The goal is in recognizing starting points, opportunities and areas, which are important for internal and external sustainability reporting, taking into, account the provisions of the globally accepted standards and the new EU Directive.

\section{INTRODUCTION}

The purpose of this paper is to present whether the accounting systems of Croatian companies are relevant source of non-financial information which need to be disclosed for external users according to Directive 2014/95/ EU (new Directive) and the framework of relevant global, EU and national sustainability reporting standards. Namely, this Directive was adopted on 22 October 2014 by The European Parliament and the European Council with the goal to amending Directive 2013/34/EU in a way that upgrades it regarding disclosure of non-financial and diversity information by certain large undertaking and groups of EU member States.

It obligates all member States to bring order of this Directive into national laws, regulations and administrative provisions, in accordance with the new guidelines which will be published by the EU Commission by December 2016, applied through the financial year 2017, to be establishing the uniform system of disclosure non-financial information from December 2018.

The emphasis is on the content, while every company can independently decide if statements will be provided separately, or the non-financial information will be included into existing financial reporting system in the way that financial information will be upgraded with the specific non-financial information. This will be a significant step towards ensuring higher quality of today voluntarily disclosed statements, because it will be the way for unifying the 
content of presented non-financial information in a way to allow benchmarking among companies, to assess the achieved level of sustainability. All this imposes the need of improvements through using accounting tools, methods and techniques, as a main source of information for long and short-term decision.

\section{THE RESEARCH METHODOLOGY AND THE COURSE OF THE RESEARCH PROCESS}

Research in this paper was focused on the evaluation of current possibilities and level of Croatian companies' preparedness to be able to implement the order of new Directive 2014/95/EU. For this purpose the quality of applied accounting tools in preparing information, necessary for segment reporting, as well as the quality of information that are nowadays presented in voluntary prepared sustainability reports was evaluated. In doing so the framework of EU and national strategic documents and policies, as well as the previous research in Croatian companies was respected.

Starting points of this research, used in accordance with the strategic approach, was the provision of Article 18 of the Croatian Accounting Act (OG 109/07; 54/13), which obligates all listed companies to disclose "information about the environment" (Art.18) as well as experiences of Croatian Business Council for Sustainable development (HR BCSD, 2013), according to which 19\% of Croatian big companies voluntarily report sustainability information and present this kind of reports on official web-site. On the other hand Article 13 of Accounting Act requires application of segment reporting standard IFRS 8, very important for short term decision making, but unfortunately provides only financial information and needs to be upgraded with some non-financial information in accordance with the requirements of EU directive, and relevant sustainability reporting standards.

Using Survey Monkey, and in order to assess the level of sustainability information quality in Croatian companies a comprehensive empirical research was conducted in year 2013 (Bakija 2014, 174-218), on the sample of 64 companies in Croatia, members of HR BCSD and Corporate social responsibility group (CSR) which voluntarily follow the principles of sustainable development in presenting sustainability reports. The emphasis was on the assessment whether, or in what extent this kind of reports, provide measurable benchmark between various industries. The questionnaire was completed by 30 companies ( $47 \%$ of the sample) and as they present around $30 \%$ of market share in Croatia, the sample could be evaluated as representative. The questionnaire includ- 
ed 48 questions following the starting points of the previous study conducted in year 2007, with the goal to enable comparison for evaluation of changes and significance for implementing the new Directive.

For this purpose it will be investigated the appropriate tools and techniques of responsibility and strategic accounting (Bebbington, Unerman, O'Dwyer 2014; Gulin, Peršić 2011), ensuring the quality of information to be presented in sustainability reports for the purposes of internal and external users, for long- and short term decision making, taking into account that many big companies in Croatia are internationally oriented and that new EU Directive opens up possibilities for a systematically evaluate their position be achieved competitive advantages on the global market, in accordance with the CSR principles (Crane, Matten, Spence 2013, 3-26). New EU Directive is particularly focused on the large undertakings, groups and big companies of public-interest, with average number of 500 employees or more that will be able to provide information, to be disclosed in the sustainability reports (English, Schooley 2014, 26-35).

\section{RESEARCH BACKGROUND}

The task of this research is to present the possibility of used strategic accounting tools, which are important for providing relevant information in the process of sustainability reporting. The part of accounting, which provides information for a long-term decision-making, is recognized as strategic accounting and for short-term decision making as responsibility accounting (Jones, Atkinson, Lorenz, Harris 2012; Drury 2012; Gulin, Persic 2011). Using strategic accounting tools is necessary in preparing information for adoption and evaluation strategy from SBU to the company level (Hoque 2006; Bebbington, Unerman, O'Dwyer 2014). Tools of responsibility accounting are very important in the way to enable assessment of sustainability objectives (as a part of strategic goals) through the narrower time periods (day, week, month, year), or narrower organizational units (responsibility centres, segments ...) that would be achieved or not (Atrill, McLaney 2007; Maher, Stickney, Weil 2008).

The starting point was the attitude that principles of sustainability are very important for creating new value for the shareholders and community (AICPA 2011, 4), and information presented in sustainability report allows the assessment of the competitive position of a certain company at the global market. Strategic accounting tools should be chosen according to internal or external 
users' needs, in the process of long-term decision making (Hoque 2006; Jones, Atkinson, Lorenz, Harris 2012). In the modern environment information on customer and employee satisfaction, products or services quality, efficiency of internal processes and other goals presented through measurable indicators, necessary for management control (Felthman \& Xie 1994; Hemmer 1996; Joseph 1999 in Banker et al. 2000, 67) in the sustainability strategies are of particular importance.

In theory and practice different strategic accounting tools, techniques and methods (Cadez \& Guilding 2008; Cadez \& Guilding 2012; Hoque 2006) connected to the different management needs are recognised. They include: strategic costing (attribute costing; life-cycle costing; quality costing; target costing; value chain costing), strategic decision making (strategic cost management; strategic pricing; brand valuation), competitor accounting (competitor cost assessment; competitive position monitoring; competitor performance appraisal), customer accounting (customer profitability analysis; lifetime customer profitability analysis; valuation of customers as assets), and Balanced Scorecard method (BSC) as the mostly used tools for strategic planning, control and performance management (Kaplan, Norton 1996; 2004; Machado 2013, 131-133).

The basic 4 perspectives of the BSC method (financial, customer, internal process and, learning and growth perspective), are seen through the concept of strategic map in a manner to be shown as the relationship among them in achieving goals. If in the existing perspectives the goals based on the sustainable development policy are added, it can be the first step for application of Sustainability Balanced Scorecard method (SBSC) method (Möller, Schaltegger 2005 , 2008). For the purposes of sustainable development, sustainability approach should be integrated in the system of integrated performance measurement system based on the basic BSC method (BSC-designer, 2014) in preparing sustainability strategy, using SBSC framework for sustainability benchmarking (Figge, Hahn, Schaltegger, Wagner 2002; Hahn, Wagner 2001; Jones, Atkinson, Loren, Harris 2012; Schaltegger, Lüdeke, Freund 2011; Hoque 2006).

SBSC method basically upgraded principle of BSC method, with the multicriteria framework that enables measurement and management in the field of sustainable development and socially responsible behaviour of companies, as they are oriented towards matching information on internal and external focus. The Sustainable Balanced Scorecard (SBSC) follows the basic concepts of BSC methods, enhanced with the qualitative, environmental and social aspects of development (Figge, Hahn, Schaltegger, and Wagner 2001) and are directed 
to linking the short-term actions with the strategic goals. In strategic decision making SBSC provides relevant information for adoption of sustainable strategies, because it provides framework for adopting goals and measurable objectives connecting financial and non-financial information, both included in the content of corporate "sustainable" strategy.

SBSC is also relevant framework of information, necessary in the process of translating sustainable principles included in company's vision and mission, to be achieved in the real time (Hahn, Wagner 2001, 4-5). Strategic goals defined in strategic plans, create framework for development of appropriate operative plans as well as yearly budgets. In order to establish control of developing strategy in the short term period it would be necessary to provide appropriate tools in responsibility accounting according to the SBSC starting points. Specification will only be possible if the system provides short term reports containing financial and non-financial information as well as the SBSC provides information for long-term decision making. Results of short-term actions should be evaluated pursuant to the 4 basic perspectives, enriched with specific ecological, social and other non-financial goals, in the manner to view interdependence among elements of the economic, ecological and social development prospects.

Sustainability reporting is basically developed from the environmental reporting, based on information prepared by environmental accounting (Rikhardsson, Bennett, Bouma, Schaltegger 2006) for the purposes of internal and external users. For the purposes of managing sustainable development, reporting system has to be based on the Triple Bottom Line (TBL) model (Majid \& Koe 2012; Elkington 1993, 1997). In voluntary manner it is globally well applied in reporting system for external users that is not adequately followed by internal sustainability reporting system. It is possible build sustainability reporting system for internal users, through upgrading the today well developed system of internal financial reporting by segments.

The conditions for global benchmarking of achieved results in sustainability development will be possible to gain, if now very good established system of financial reporting, based on International Financial Reporting standards (IFRS), provision of financial Directive (2013/34/EU) and national legislation, will be upgraded with those non-financial and bio-diversity information (minimum of environmental, social and employee matters, in respect for human rights, anti-corruption and bribery matters). Today voluntary prepared sustainability reports for external users, through the adoption of the new EU 
Directive, will become mandatory and uniform. That means inclusion of nonfinancial information in those reports which today present only financial information, based on provision of IFRS 27 for enterprises (independent entities) or IFRS 10 for complex systems, such as chains and multinational corporations.

\section{THE OUTCOME OF THE RESEARCH PROCESS AND CONCLUSIONS}

Following the provisions of the Croatian Accounting Act the sample mostly represented big companies (70\%), which are obligated to apply the provision of the Directive 2014/95/EU. The response was submitted mostly from business function managers $(65 \%)$ or the board members $(30 \%)$. The sample included manufacturing sector (37\%), tourism and hospitality industry (33\%), commerce (8\%), telecommunication (7\%) and others. The sample consisted of $60 \%$ of those companies that have the status of a joint stock company (50\% of them listed their shares on the stock exchange) and the remaining are limited liability companies.

Investigated companies have mainly or fully domestic private ownership (27\%), mainly or fully foreign ownership (23\%), mainly or fully state ownership - parent company or subsidiary (20\%), mainly or fully foreign private ownership (17\%) or subsidiary of foreign company (13\%). The strategic goals of Croatian companies are in highest rank connected to the needs of improving their market position (sales growth, customer satisfaction, new product development and launching into new markets), while the goals relating to improvement of relations with the employees and local community, as well as the cost rationalization are somewhat lower ranked according to the sustainability priorities positioned among (5) for the best and (1) for the lowest ranked score.

Environmental protection and improvement as well as upgrading the relations with the community is ranked exactly as timely debt collection and motivating employees for lifelong learning (4.43). Improvement of technological support of development is not positioned on the appropriate level (4.29), while reducing the number of total employees is ranked as the least important factor (3.50) for sustainable development of Croatian companies. Particular emphasis is placed on evaluating the postulates on which sustainability reporting system can be drawn up, as well as the assessment of impact of sustainable development on the success of the companies on the global market. To be able to assess trends in sustainable development, the research results of current investigation with the results of relevant data presented in previous study, con- 
ducted in Croatia followed by UNDP experts (Bagić, Miošić-Lisjak, Škrabalo 2007) will be shown.

As the EU directive provides only a legal framework for its implementation it is necessary to include relevant standards, schemes and examples of good practice in order to ensure the uniformity in the stage of preparing strategy as well as in the evaluation of achieved results, because it ensures the application of measurable indicators (KPIs) and the comparability of the achieved results in the short and long term.

As the support of strategic management it is recommended to use specific global, EU-regional or national standards or regulations, as well as ISO standards (14000ff, 26000 ...), GRI (Global Reporting Initiative), UN Global Compact, OECD Guiding Principles on Business and Human Rights, EMAS (Eco-Management and Audit Scheme), and other recognised frameworks at global, regional or local level. Responsibility accounting uses common accounting or industry standards in preparing financial information on segments (IFRS 8, IPSAS 18, USALI, USAR, USFRS ...), which are made according to the provisions of Directive 2014/95/EU. Several results of empirical research will be presented and analysed.

Figure 1. Quality \& Eco- reporting framework used by Croatian companies

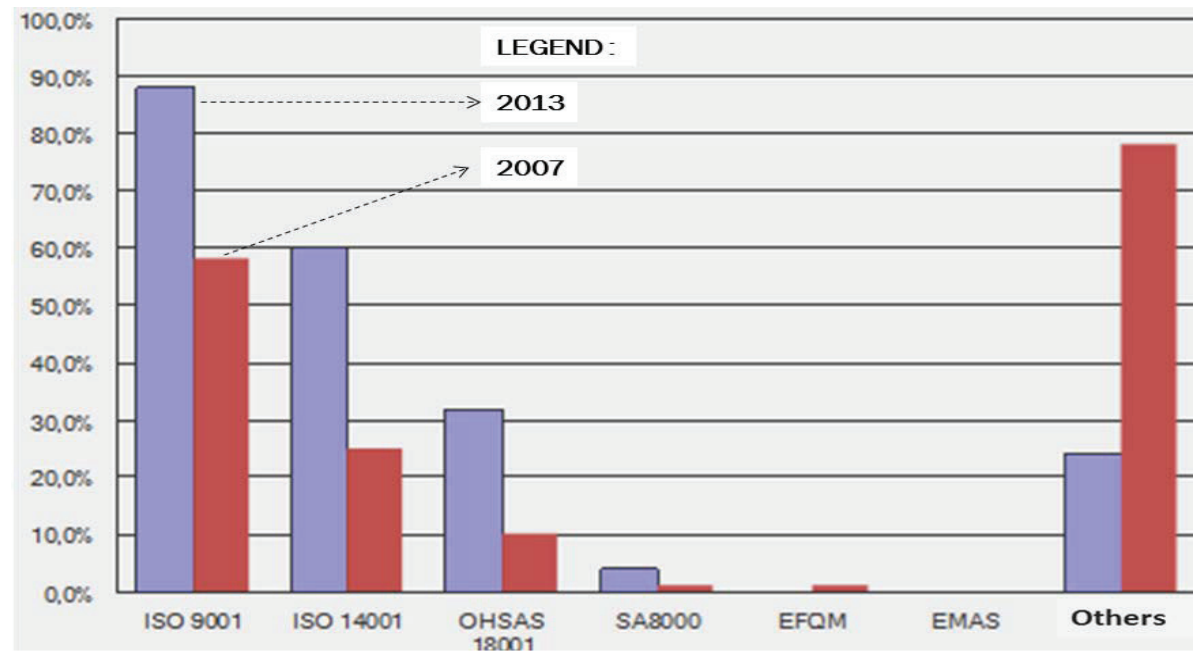

S o u r c e : Results of empirical research. 
The figures above indicate that Croatian companies mostly apply principles of the quality ISO standards of total quality management (certification to ISO 9001), but not in the same way the EFQM norm. Much less are present the standards in field of improve and protection of environment (certification to ISO 14001), as well as the framework for an occupational health and safety management system and working conditions, aligned to internationally recognized best practice (certification to BS OHSAS 18001).

While in previous years was applied different national standards, indicators and criteria, which follow national environmental policy (waste, water, CO2 emissions, gas emissions) defined through the National Sustainable Development Strategy and Environmental Protection and Energy Efficiency Fund of the Republic of Croatia, in recent years have given way to priority of application internationally accepted standards. In the EU widely applied standard EMAS (Eco Management and Audit Scheme). In comparison to the previous survey significant progress in Croatian companies can be noted in certification of different company processes, using international recognised quality, and ecoquality standards.

Figure 2. Sustainability reporting framework used by Croatian companies

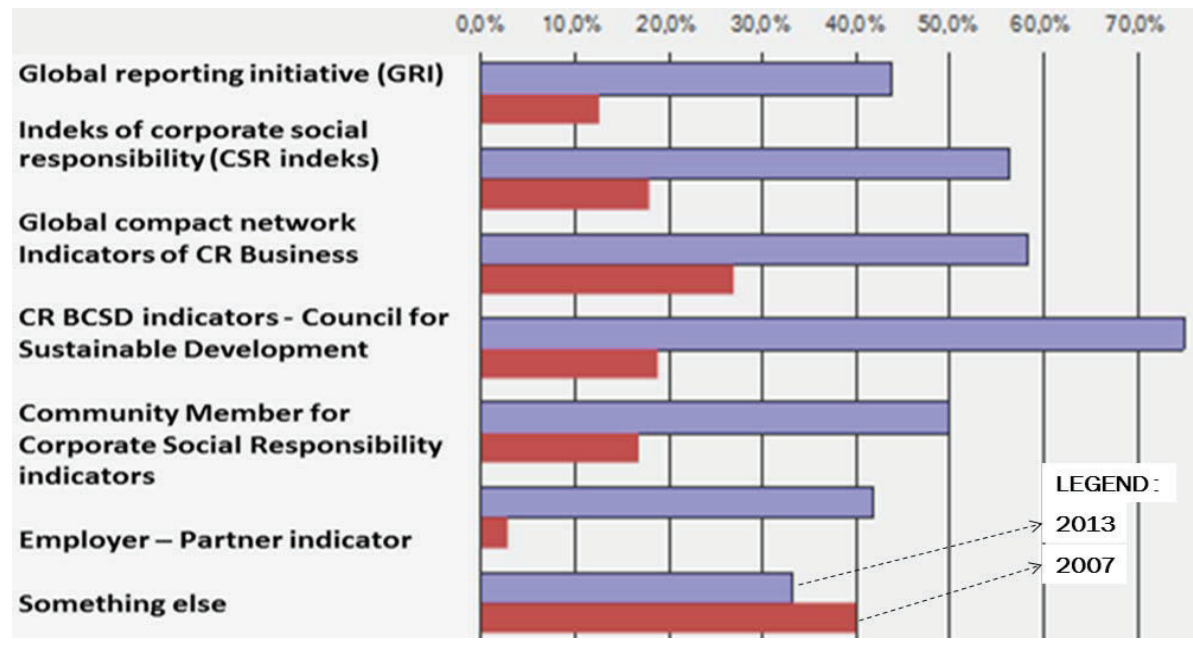

S o u r c e : Results of empirical research.

Further improvements can be expected, if through the national legislation will be implemented new requirements of EU Directive in field of disclosure 
non-financial information. The success of the implementation of the new EU Directive can guarantee the relationship with globally recognized sustainability reporting standards. The next picture present the experiences of sustainability oriented Croatian companies, in using sustainability standards in preparing sustainability reports for external users.

Croatian companies follow globally recognised principles of sustainability reporting (GRI, UN Global Compact's requirements, CSR index), although is the first place reserved for national standards (CR BCSD indicators) prepared by Croatian Council for Sustainable Development or other prepared on the local or corporate level. Sustainability reporting is very important because mostly Croatian companies are oriented towards foreign market (proof $45 \%$ of investigates companies in the sample gaining more than $50 \%$ of revenue on the foreign markets). Looking more closely to the sustainability element of development, respondents in Croatian companies placed the greatest importance on compliance with the sustainability regulations $(100 \%)$, which is in some way the precondition for future successful implementation on new Directive.

As is the sustainable development the strategic priority of modern business, sustainability reporting system has to be also strategically oriented. Research results show that $60 \%$ of Croatian companies prepare long-term goals in the frame of strategic plans, which should be prepared in accordance with the strategic management requirements. Research results show that the highest priority of strategic management in Croatian companies is given to ensuring customer satisfaction (90\%), following regular payment of salaries (87\%), sales growth (80\%), cost reduction (79\%), new product development (65\%). As can be seen in the following figure, Croatian managers are primarily focused on the achievement of economic objectives.

Unfortunately, environment care (59\%) are not ranked as the highest priority, as well as the improvement of relations with the community (53\%), thus the environmental and social objectives are ranked lower than economic. In strategic approach financial and non-financial goals are interlaced and higher emphasis is on the use of financial indicators in the process of preparing and evaluating the strategy. It is therefore necessary to act in direction of raising awareness of management in field of sustainable development, through the competition of sustainability results, based on benchmarking of presented sustainability information for external users. 
Figure 3. Ranking priority of strategic goals in the Croatian companies

SALES GROWTH
COST REDUCTION
ESPANSION INTO NEW MARKETS
NEW PROCUST DEVELOPMENT
IMPROVING THE TECH. PROCESS
CUSTOMER SATISFACTION
UPGRADING OF EMPLOYEES
KNOWLEDGE
THE REGULARY PAYMENTS
STAFF REDUCTIONS
PAYMENT OF RECEIVABLES
ENVIRONMENT CARE
IMPROVE RELATIONS WTH THE
COMMUNITY

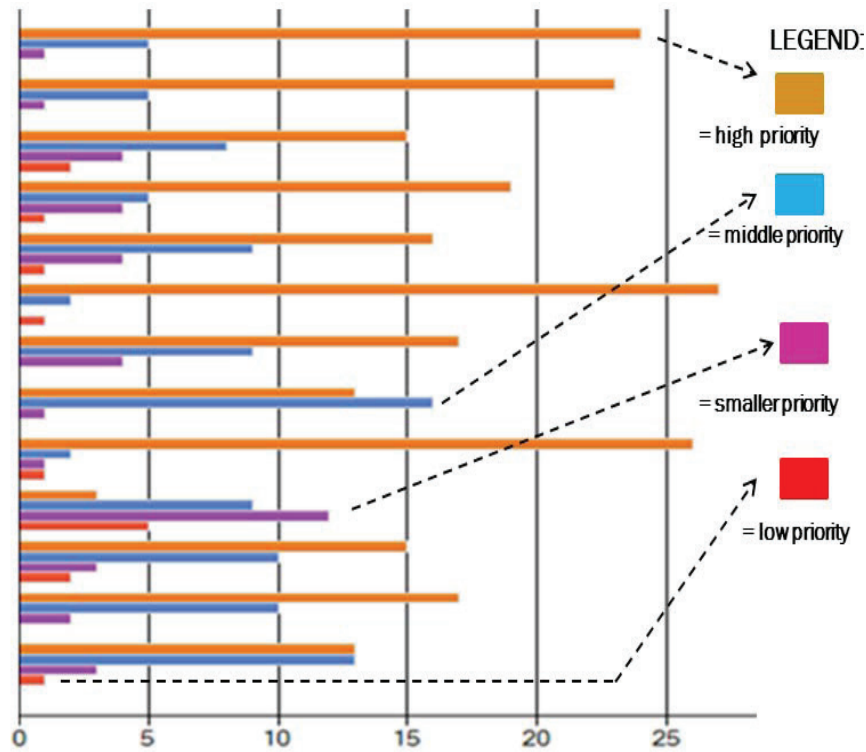

S o u r c e : Results of empirical research.

Sustainable reporting system of Croatian companies outlines the website of HR BCSD where members of Corporate Social Responsibility Group collected and presented their results in sustainability report through different names and content. The most commonly used term is "Report of Sustainable Development" $(34,7 \%)$ or "Sustainability Report" (22,2\%), following by "Environmental protection report" (15,3\%), "Report on socially responsible business", "Corporate Social Responsibility", "Social report", "Sustainability and social responsibility report", "Progress Report" (1,4\% - to the 9,7\%), or simply "Annual Report" (4\%).

In the last three years of examination, only about $5 \%$ of listed companies in Croatia disclosed their sustainability report for public use. As their volume, manner and character are very different, presented information is not suitable for comparison, and need to be used minimum of common indicators as a prerequisite for introduce benchmarking process. Until then, these reports will remain to satisfy formality, and not with the intention to be really involved in the process of achieving goals of sustainable development presented, as presented in the National Sustainable Development Strategy. Some activities of HR BCSD and CSR group indicate that can be expected improvements through using CSR 
Index (Omazi, Vlahov 2011, 44-52), on which may be based benchmarking of sustainability results of Croatian companies.

The quality of sustainability information presented in reports for external users and directed in the process of strategic planning, depends of quality of internal accounting and system of collecting and presenting sustainability information on the daily and monthly level, which required high level of harmonization between internal and external sustainability reporting system. Starting point to achieve this goals are good experiences of segment (financial) reporting, widely used in Croatian companies and based on using International Financial Reporting Standard 8 (IFRS 8 2009) or other segment reporting standard, prepared for specific needs of some industry or goals groups (USALI 2014; USAR 2012; USFRS 2005), as well as for public sector purpose (IPSAS 18).

AS provisions of Accounting Act in Croatia, obligate all large listed companies to disclose segment information, the aim was to investigate the extent to which those provision are applied consistently. Also were used numerous of earlier studies conduct in Croatian companies, in which authors have been directly or indirectly involved (Ilić 1997; Turčić 2000; Zanini 2004 \& 2011; Peršić, Janković 2006; Peršić, Janković, Vlašić, Vejzagić 2007; Peršić, Peruško-Stipić 2009; Poldrugovac 2009 \& 2011; Janković, Peršić, Zanini-Gavranić 2011; Janković, Peršić 2011; Peršić, Poldrugovac 2011; Peršić, Janković 2010, 2011; Peršić, Janković, Poldrugovac 2012; Vejzagić, Peršić, Janković 2012; Vlašić 2012) shown the developed level of segment reporting in Croatian companies. Further to this, the objective was to evaluate the position of segment reporting of Croatian listed companies, which present financial reports through Croatian Financial Agency (CFA) and their shares list on the ZSE (Zagreb Stock Exchange). It was used National sector classification (25 different industries) in accordance with Global Industry Classification Standard (GICS). Examined results of this empirical research for year 2013, are presented in the following table.

It is evident that only $23,8 \%$ of listed Croatian companies disclose financial information by segment. For the purpose of sustainability reporting the existing system of segment reporting should be upgraded and improved with the specific non-financial information, following sustainability reporting standards and the elements of the Guidebook in compliance with the provisions of Directive 95/2014/EU, and directed to achieve goals of sustainable development. The harmonisation between internal and external sustainability reports is directed to better assessing divisional performance (Atrill \& McLaney 2007, 374-376) and also contribute to higher environmental and social responsibility information. 
Table 1. Segment reporting information present in the listed companies in Croatia

\begin{tabular}{|c|c|c|c|}
\hline $\begin{array}{l}\text { Industries According to The Global Industry Classification Standard } \\
\text { and National Classification Sector }\end{array}$ & $\begin{array}{l}\text { Examined } \\
\text { listed } \\
\text { companies }\end{array}$ & $\begin{array}{c}\text { Companies } \\
\text { which present } \\
\text { segmental } \\
\text { information }\end{array}$ & $\begin{array}{l}\%(2) \\
\text { of (1) }\end{array}$ \\
\hline 0 & 1 & 2 & 3 \\
\hline $\begin{array}{l}\text { 74. Business services (legal, accounting, architecture, engineering, } \\
\text { technical testing, analysis ...) }\end{array}$ & 10 & 4 & 40,0 \\
\hline 40. / 65. Finance \& Insurance & 33 & 12 & 36,4 \\
\hline 55. Accommodation / Food \& Beverage & 41 & 13 & 31,7 \\
\hline 30. Food, Beverages \& Tobacco Products & 22 & 5 & 22,7 \\
\hline 31. / 32. Manufacture of electrical equipment & 9 & 2 & 22,2 \\
\hline 20. / 61. - 63. Transportation and storage & 12 & 2 & 16,7 \\
\hline $\begin{array}{l}\text { 15.-21. / 24-36. Production of wood and paper products; coke, and re- } \\
\text { fined petroleum products; chemicals and chemical products; pharma- } \\
\text { ceutical products and preparations; computer, printer, electronic and } \\
\text { optical products; textiles, apparel, leather; rubber, plastics products, } \\
\text { non-metallic mineral product; metals products; machinery and transport } \\
\text { equipment }\end{array}$ & 30 & 5 & 16,7 \\
\hline 42. Construction & 10 & 1 & 10,0 \\
\hline All other activities & 29 & 5 & 12,8 \\
\hline Total & 206 & 49 & 23,8 \\
\hline
\end{tabular}

S o u r c e : Results of empirical research of Croatian listed companies for the year 2013.

Information needed for reporting system and benchmarking process, should be available directly from the accounting information system (environmental and / or sustainability accounting), which means that it must be every business event registered on the place where business impact on environment and community was made, and in real time when incurred (Jianu, Jianu, Raileanu 2011). In harmonization process has to be follow requirements of standard ISO $14000 f f$, Global Reporting Initiative, UN Compact, EMAS, national or corporate indicators, as a base for guiding corporate actions towards achieving sustainable development goals from the lowest to the highest level of the companies' decision making system (Banker, Potter, Srinivasan 2000; Brander Brown, McDonnell 1995; Mia, Patiar 2001; Philips 1999; Pavlatos, Paggios 2009). Harmonisation of internal and external sustainability reporting system is imposed as a necessity and would be based on relevant accounting tools and supported by information technology and software. 


\section{CONCLUSION}

Sustainable reporting system of Croatian companies should be based on sustainable strategies, respect the provisions of Directive 2014/95/EU and globally recognized sustainability standards and supporting through the high level of IT. Accounting information system as a source of sustainability information, should systematically respond to new sustainability management requirements, and provide framework for benchmarking, and for evaluating how sustainability strategies are performed. Fields of adapting contemporary accounting to the new sustainability requirements are presented in the figure.

Figure 4. From financial to sustainable reporting - regulations and standards

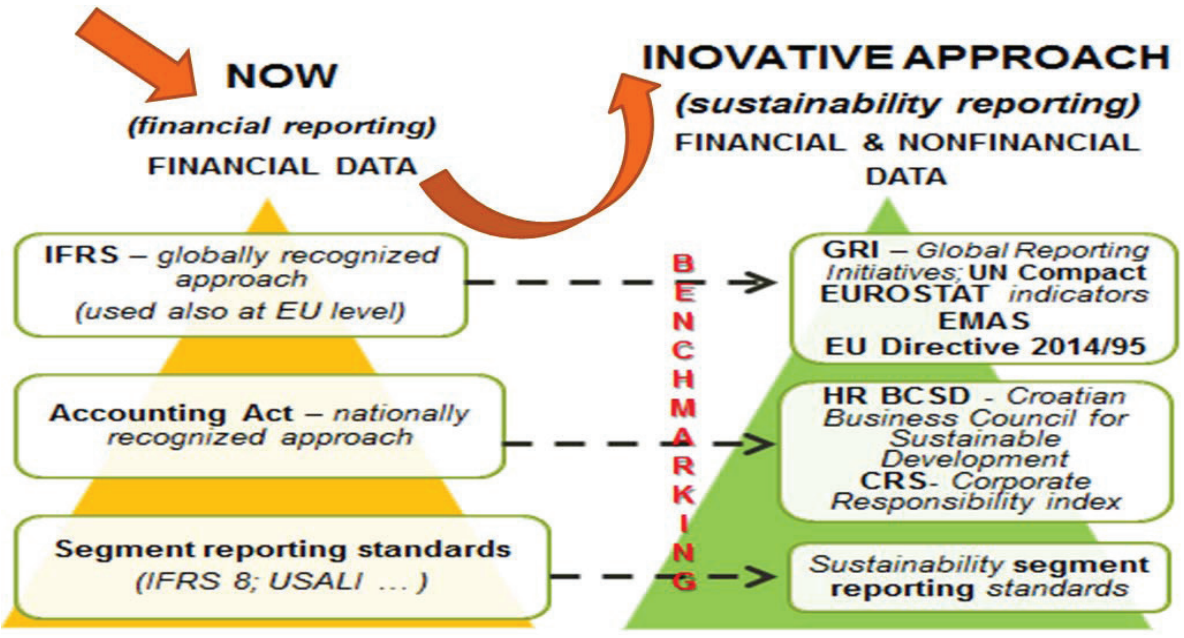

S o u r c e : Proposed by authors.

Special emphasis would be placed on the harmonization between segment and external reporting system, strategic planning based on the SBSC method requirements, through the combination of presented financial and non-financial information, in accordance with the principle of sustainable development, presented in the EU strategies, for "Corporate Social Responsibility" and "The Europe 2020" (Marlier, Natali, Van Dam 2010), and take into account specifics of the particular circumstances of a single company. The process starts with the policy for protection natural resources, be focused on sustainability of product and services, and oriented on create value for community, costs re- 
duction increase the benefits for users, and to protect of the planet earth. The research results show that in Croatian companies are present certain prerequisites for the successful implementation provisions of EU Directive 2014/95/ $\mathrm{EU}$, through the national legislation framework and through the introduction of benchmarking process, which should lead to evaluation and rewarding those companies /managers that most successfully apply the principles of sustainability, noting that modern accounting should play in this process, very important role.

\section{REFERENCES}

AICPA (2012). American Institute of CPAs, retrieved 12.10.2014.

Atrill, P., \& McLaney, E. (2007). Management Accounting for Decision Makers, FT Prentice Hall, Financial times, Pearson Education London, New York, Boston.

Bagić, A., Miošić-Lisjak, N., \& Škrabalo, M. (2007). Report on corporate social responsibility in Croatia, a part of project „Accelerating CRS practice in the new EU member States and candidate countries as vehicle for harmonization, competitiveness and social cohesion in the EU, UNDP _ United Nations Development Programme, Croatia.

Bakija, K. (2014). Accounting information for managing sustainable corporations development, Računovodstvena informacije za upravljanje održivim razvojem korporacije, PhD thesis, Faculty of Tourism and Hospitality Management, Opatija, University of Rijeka.

Bebbington, J., Unerman, J., \& O’Dwyer, B. (2014). Sustainability Accounting and Accountability, Routledge, Taylor \& Francis Group, London and New York.

BSCdesigner. (2014). Balanced Scorecard http://www.bscdesigner.com/bsc-for-hoteltop-management.htm (accessed: 22.09.2014).

Banker, R. J., Potter, B., \& Srinivasan, D. (2000). An Empirical Investigation of an Incentive Plan that Includes Nonfinancial Performance Measures, The Accounting Review, 75 (1), 65-92. http://dx.doi.org/10.2139/ssrn.67808.

Brander Brown, J., \& McDonnell, B. (1995). The Balanced Scorecard: Short-term guest or Long-term Resident?, International Journal of Contemporary Hospitality Management, 7 (2), 7-11. http://dx.doi.org/10.1108/09596119510146751.

Cadez, S., \& Guilding, C. (2008). An exploratory investigation of an integrated contingency model of strategic management accounting, Accounting, Organizations and Society, 33, (7), 836-863, http://dx.doi.org/10.1016/j.aos.2008.01.003.

Cadez, S., \& Guilding, C. (2012). Strategy, strategic management accounting and performance: a configurational analysis, Industrial Management \& Data Systems, Emerald Group Publishing Limited 112 (3), 484-501. http://dx.doi.org/10.1108/0263557 1211210086.

CFA (2013). Croatian Financial Agency (FINA) - Corporate - Services and Products for Companies and Sole Traders (http://www.fina.hr/Default.aspx?sec=1147). 
Crane, A., Matten, D., \& Spence, L.J. (2013). Corporate Social Responsibility: Readings and Cases in a Global Context, 2/e. Abingdon: Routledge, 3-26.

Croatian Accounting Act (OG 109/07; 54/13).

CSR (2010). A Guide to CSR in Europe - Country Insights by CSR Europe's National Partner Organisation, CSR Europe, http://www.dop.hr/; http://www.hrpsor.hr/ (accessed: 13.02.2015).

Drury, C. (2012). Management and Cost Accounting, 8 Ed, Cengage Learning, Australia, Brazil, USA.

Elkington, J. (1993). Coming clean: The rise and rise of the corporate environmental report. Business Strategy and the Environment, 2(2), 42-44.

Elkington, J. (1999). Triple bottom-line reporting: Looking for balance. Australian CPA, (March), 19-21.

EMAS http://ec.europa.eu/environment/emas/documents/legislative_en.htm; http:// ec.europa.eu/ environment/emas/pdf/factsheet/fs_EMAS2to3.pdf (accessed: 22.02. 2014).

EPEEF (2003). Environmental Protection and Energy Efficiency Fund of the Republic of Croatia (OG 107/2003).

English, M. D., \& Schooley, D. K. (2014). The Evolution of Sustainability Reporting, The CPA Journal (March), 26-35.

EU Directive 2013/34/EU - Annual financial statements, consolidated financial statements and related reports of certain types of undertaking, The European Parliament and of the Council and repealing Council Directives, of 26 June 2013, 78/660/ EEC and 83/349/EEC Text with EEA relevance (accessed: 12.11.2014).

EU financial directive 2014/95/EU - Disclosure of non-financial and diversity information by certain large undertakings and groups (amending EU Directive 2013/34/ EU), The European Parliament and the Council of 22 October 2014, http://eur-lex.europa.eu/legal-content/EN/TXT/?uri=CELEX:32014L0095 (accessed: 23.12.2014.)

Figge, F., Hahn, T., Schaltegger, S., \& Wagner, M. (2001). Sustainability Balanced Scorecard- Wertorientiertes Nachhaltigkeitsmanagement mit der Balanced Scorecard, Centre for Sustainability Management (CSM), University of Luneburg, BMBF Project.

Figge, F., Hahn, T., Schaltegger, S., \& Wagner, M. (2002). The Sustainability Balanced Scorecard- Linking Sustainability Management to Business Strategy, Centre for Sustainability Management, University of Luneburg, Business Strategy Environment, $11,269-284$.

GICS - Global Industry Classification Standard and National classification (OG 58/07).

GRI, Global Reporting Initiative - G4 - Sustainability Reporting Guidelines - Reporting principles and Standard Disclosures \& Implementation Manuel, https://www. globalreporting.org/reporting/g4/P/default.aspx (accessed: 11.11.2014).

Gulin, D., \& Peršić, M. ed., (2011). Managerial Accounting //Upravljačko računovodstvo, HZFRD, Hrvatska zajednica računovođa i financijskih djelatnika, Zagreb.

Hahn, T., \& Wagner, M. (2001). Sustainability Balanced Scorecard-Von dem Theorie zur Umsetzung, Lehrstuhl für Betriebswirtschafslehre, Umweltmanagement Universität Lüneburg, Centre for Sustainability Management. 
Hoque, Z. (2006). Strategic Management Accounting, Concepts, Processes and Issues, 2nd Edition, Pearson Education Australia, Frenchs Forest, Australia.

HR BCSD (2013). official web-site http://www.hrpsor.hr or Croatian Business Council for Sustainable Development, http://www.csreurope.org/croatian-business-council-sustainable-development (accessed: 14.12.2013).

IFRS 8 - International Financial Reporting Standard 8 (2006-2013), http://www.iasplus.com/en/standards/ifrs/ifrs8 (accessed: 30.11.2014).

IFRS 10 - Consolidated Financial Statements, http://www.iasplus.com/en/standards/ ifrs/ifrs10 \& IAS 27 Separate Financial Statements, http://www.iasplus.com/en/ standards/ias/ias27-2011 (accessed: 14.04.2015).

ISO 14001:2004, http://www.tuv-nord.com/hr/certifikacija-sustava/iso-14001-455. htm (accessed: 24.05.2014).

IPSAS 18 (2014) International Public Sector Accounting Standard, IFAC, http://www. ifac.org/public-sector (accessed: 23.11.2014).

Ilić, S. (1997). Performance Budgeting in the Croatian Hospitality Industry, Master Thesis (Mentor M. Peršić), Faculty of tourism and hospitality management, Opatija.

Janković, S., Peršić, M., \& Zanini-Gavranić, T. (2011). Framework for Development of Environmental Management Accounting (EMA) in Croatian Hospitality Industry, international conference, Tourism in SEE, 1, Faculty of Tourism and Hospitality Management, 121-136.

Jianu, I., Jianu, I., \& Raileanu, A. S. (2011). Financial Reporting and Social Responsibility, Bucharest Academy of Economic Studies, Romania, EAA. L.

Jones, T., Atkinson, H., Lorenz, A., \& Harris, P. (2012). Strategic Managerial Accounting, VI Ed. Goodfellow Publishers Ltd Woodeaton, Oxford.

Kaplan, R., \& Norton, D. (1996). The Balanced Scorecard - Translating Strategy into Action, Harvard Business School Press, Boston, Massachusetts.

Kaplan, R., \& Norton, D. (1996). Using the Balanced Scorecard as a Strategic Management System, Harvard Business Review January-February 1996.

Kaplan, R.S., \& Norton, D.P. (2004). Strategy Maps - Converting Intangible Assets into Tangible Outcomes, Harvard Business School Press, Boston, Massachusetts.

Majid, I. A., \& Koe, W. L. (2012). Sustainable Entrepreneurship: A Revised Model Based on TBL. International Journal of Academic Research in Business and Social Sciences, (12), 6.

Marlier, E., Natali, D., \& Van Dam, R. (2010). Europe 2020 - OSE, P.I.E. Peter Lang, Brüssel.

Machado, M.J.C.V. (2013). Balanced Scorecard: an empirical study of small and medium size enterprises, Review of Business Management, FECAP, 15 (46), 129-148. http:// dx.doi.org/10.7819/rbgn.v15i46.1175.

Maher, M.V., Stickney, C.P., \& Weil, R. L. (2008). Managerial Accounting, Thomson, South Western, Australia, Brazil, Canada, Mexico.

Mia, L., \& Patiar, A. (2001). The use of management accounting systems in hotels: an exploratory study. International Journal of Hospitality Management, 20, 111-128. 
Möller, A., \& Schaltegger, S. (2005). The Sustainability Balanced Scorecard as a Framework for Eco-efficiency Analysis, Journal of Industrial Ecology, 9 (4), 73-83. http:// dx.doi.org/10.1162/108819805775247927.

NSDS (2009). National Sustainable Development Strategy (OG 30/09 \& 110/07).

National classification (OG 58/07).

Omazi, M.A., \& Vlahov, R.D. (2011). CSR Index as a Strategic Management Tool in Croatia, Phase I \& II, International Journal of Management Cases, 13 (2), 44-52. http:// dx.doi.org/10.5848/apbj.2011.0031.

Pavlatos, O., \& Paggios, I. (2009). A survey of factors influencing the cost system design in hotels, International Journal of Hospitality Management, 28, 263-271.

Peršić, M., \& Janković, S. (2006). Menadžersko računovodstvo hotela, FTHM, Opatija \& HZRFD, Zagreb.

Peršić, M., Janković, S., Vlašić, D., \& Vejzagić, V. (2007). Internal audit and environmental hotel management requirements 30th Annual Congress of EAA, Lisbon, Portugal, (25-27.04.2007).

Peršić, M., \& Poldrugovac, K. (2009). Segment Reporting in Harmonization and Globalization Processes, 1st International Scientific Conference Knowledge and Business Challenges of Globalization, Faculty for Commercial and Business Sciences, Celje (accessed: 12-13.11.2009).

Peršić, M., \& Janković, S. (2010). Uniform System of Accounts for the Lodging Industry and Performance Benchmarking, 2. International scientific conference Knowledge and business challenge of globalization, Faculty of commercial and business sciences, Celje, (18-19.11.2010).

Peršić, M., \& Poldrugovac, K. (2011). Accounting Information for Sustainability Management in the Hospitality Industry, 3rd International scientific conference: Knowledge and challenges of Globalization in 2011, Faculty of Commercial and Business Sciences Celje, November 17th-19th.

Peršić, M., \& Janković, S. (2011), Performance Benchmarking Tool in the Croatian Hotel Industry, Advances in Food, Hospitality and Tourism, 1 (4).

Peršić, M., Janković, S., \& Poldrugovac, K. (2012). Implementation of Segment Reporting Standards in the Hospitality Industry - A Comparative Study, New Trends in Tourism and Hospitality Management, Faculty of Tourism and Hospitality Management, 30-39.

Peruško Stipić, D. (2010). IT support for accounting information system in hospitality industry. Master thesis, Faculty of tourism and hospitality management Opatija, University of Rijeka, (defence: 15.04.2010).

Phillips, P. A. (1999). Hotel performance and competitive advantage: A contingency approach. International Journal of Contemporary Hospitality Management, 11, 359-365.

Rikhardsson, P. M., Bennett, M., Bouma, J. J., \& Schaltegger, S. (2006). Implementing Environmental Management Accounting: Status and Challenges, EMAN, Springer, Dordrecht, Netherlands.

Schaltegger, S., \& Lüdeke, F. (2011). The Sustainability Balanced Scorecard, Concept and the Case of Hamburg Airport, Centre for Sustainability Management (CSM), Leuphana Univeristät Lüneburg. 
Turčić, M. (2001). Accounting reporting system in hospitality industry, Master thesis, Faculty of business and economic, University of Zagreb (20.04.2001).

USALI (2014). Uniform System of Accounts for the Lodging Industry, XI Ed, Hotel Association of New York City, New York, Hospitality Financial and Technology Professionals Austin, Texas, America Hotel and Lodging Educational Institute, Orlando, Florida.

USAR (2012). Uniform System of Accounts for Restaurants, National Restaurant Association, USA.

USFRS (2005). Uniform System of Financial Reporting for SPAs, International SPA organisation, Hospitality Financial and Technology Professionals, USA.

UN Global Compact, http://globalcompactfoundation.org/about-ungc.php (accessed: 01.08.2014).

Vejzagić, V., Peršić, M., \& Janković, S. (2012). Challenges of Environmental Accounting in Tourism Destination as a Trend of Sustainable Development, [in:] EMERALD, Special Issue, Aras, G., \& Crowther, D. (eds.), Developments in Corporate Governance and Responsibility, 231-244.

Vlašić, D. (2012). Internal audit as a support for environmental management in the hospitality industry, (mentor M.Peršić), University of Rijeka, Faculty of tourism and hospitality management, Opatija.

Zanini Gavranić, T. (2004). Managerial accounting in the TQM (MrS thesis, mentor M.Persic), University of Rijeka, Faculty of tourism and hospitality management, Opatija.

Zanini Gavranić, T. (2011). Accounting preconditions for preparing information for business decision-making in hospitality industry, (PhD thesis, mentor M. Persic) University of Pula, Economy and Tourism Dr M. Mirković Pula (defense: 03.06. 2011). 
